\title{
Yoshitsune Crossing the Ocean: The Tale of Onzōshi Shimawatari
}

\author{
SAITŌ Maori \\ Translated by Kristopher ReEves
}

$\mathrm{P}$ erformative works from various genres—nō 能, kōwakamai 幸若舞, kojōruri 古浄瑠璃—that foreground episodes in the life of Minamoto no Yoshitsune 源義経 (1159-1189) and his immediate circle are collectively referred to as bogan mono 判官物, a term taken from the fact that Yoshitsune himself served as lieutenant of the imperial police ( $h \bar{g} g a n)$. Many of these episodes where circulated and enjoyed in the form of picture books (so-called Nara ehon 奈良絵本) and illustrated scrolls, a great many of which focused on events taken from Yoshitsune's younger years. One of the more noteworthy events takes the form of a fantastic legend in which Yoshimitsu succeeds in obtaining a manual containing esoteric teachings of martial strategy. An adaptation of this legend appears in the second fascicle of Gikeiki 義経記 (The Chronicle of Yoshitsune), for example, contains a section, entitled "Yoshitsune Pays His Respects to Venerable Master Kiichi or Oniichi 鬼一, ” wherein readers are treated to a tale of martial courage and ill-fated love.

A fine example of how this same legend was adapted into the world of popular fiction is to be found in a vernacular tale (otogi zōshi 御伽草子) entitled Onzōshi shimawatari 御曹子島渡り (Yoshitsune's Island Hopping). ${ }^{1}$ The first part of the title of this tale, onzōshi, is a polite term used to refer to the son of a high-ranking, well-to-do father who has not yet gained own independence. This term eventually came to serve as an epithet for Yoshitsune, at least during his early years. Vernacular tales of this sort, compiled and published between the fourteenth and seventeenth centuries, often included illustrations, thereby taking the form either of picture books or illustrated scrolls. These works grant us a glimpse into the visual culture of medieval Japan. Despite much research, in most cases, neither the authors nor the illustrators of these works are known. This is so in regards to Onzōshi shimawatari, of which only ten manuscripts, including both

\footnotetext{
${ }^{1}$ For an English translation by Charles Woolley of this vernacular tale, complete with illustrations, see Keller Kimbrough and Haruo Shirane, ed., Monsters, Animals, and Other Worlds: A Collection of Short Medieval Japanese Tales, New York: Columbia University Press, 2008, pp. 149-165.
} 
woodblock and fragmentary editions, are currently known to be extant.

In recent years, however, an exceptionally beautiful manuscript of this tale, consisting of three large-sized illustrated scrolls completed sometime in the seventeenth century was discovered among the Ikenoya Collection いけのや文庫. In August, 2017, the National Institute of Japanese Literature made these scrolls available to the public in the form of digitalized images available on-line. ${ }^{2}$ It is believed that the Ikenoya MS was produced in the same studio that compiled what is now known as the Kuyō Collection 九曜文庫 MS of Onzōshi shimawatari, considering a number of striking similarities found in both manuscripts.

A summary of the tale as found in this Ikenoya MS is in order. Yoshitsune, at the recommendation of a certain Hidehira of the Northern Fujiwara clan, undertakes a long sea voyage in hopes of obtaining a rare manual of martial strategy entitled Dainichi no hō 大日の法, or, Stratagem of the Great Sun. This esoteric manual, we are told, is in the hands of Great King Kanehira かねひら大王, an demonic, ogre-like lord, who dwells in Kiken Castle 喜見城, somewhere in the northern lands of the Emishi tribes. Yoshitsune sets out from the port at Tosa and arrives at the northern castle only to have his request denied outright: Great King Kanehira is not willing to reveal his secret manual to the young visitor. Undaunted by this initial rebuff, Yoshitsune manages to enlist the aid of Asahi Tennyo 朝日天女, Divine Maiden of the Morning Sun, a princess at Kanehira's court, who promises to assist the young man by making a copy of the manual. No sooner had she copied the pages of the manual than the text of the latter was magically erased, leaving only a blank scroll. Fearing the wrath of Kanehira, Princess Asahi quickly ensures that Yoshitsune is safely sent away from the island, copied scroll in hand. Unfortunately, the princess was unable to preserve her own life, slain as she was at the hands of an enraged Kanehira. In the end, it is revealed that Princess Asahi was actually a temporary manifestation of Benzaiten, a goddess whose abode was believed to be on Enoshima 江の島, Kanagawa. This goddess, in an act of divine intervention, deigned to descend to this mortal world in the form of a maiden and, allowing herself to be married to the demonic Kanehirae, succeeded in assuring the victory of the Minamoto clan over their-and evidently her-rivals, the Taira clan. Armed with his newfound esoteric martial teachings, Yoshitsune was able to defeat the Taira forces, thereby fulfilling Benzaiten's wish.

Some research has already been done in regards to similarities between Onzōshi shimawatari and another popular vernacular tale entitled Kibune no bonji 貴船の本 地 (The Original Buddha of Kibune), insofar as both tales depict the tragic love affair between the mortal son of a high-ranking father, on the one hand, and the divine princess of a demonic overlord, on the other. Furthermore, investigations into the cultural background inspiring tales of secretly transmitted manuals or other written material has brought to light the relationship between such practices and

\footnotetext{
${ }^{2}$ See https://kotenseki.nijl.ac.jp/biblio/100257436/viewer.
} 


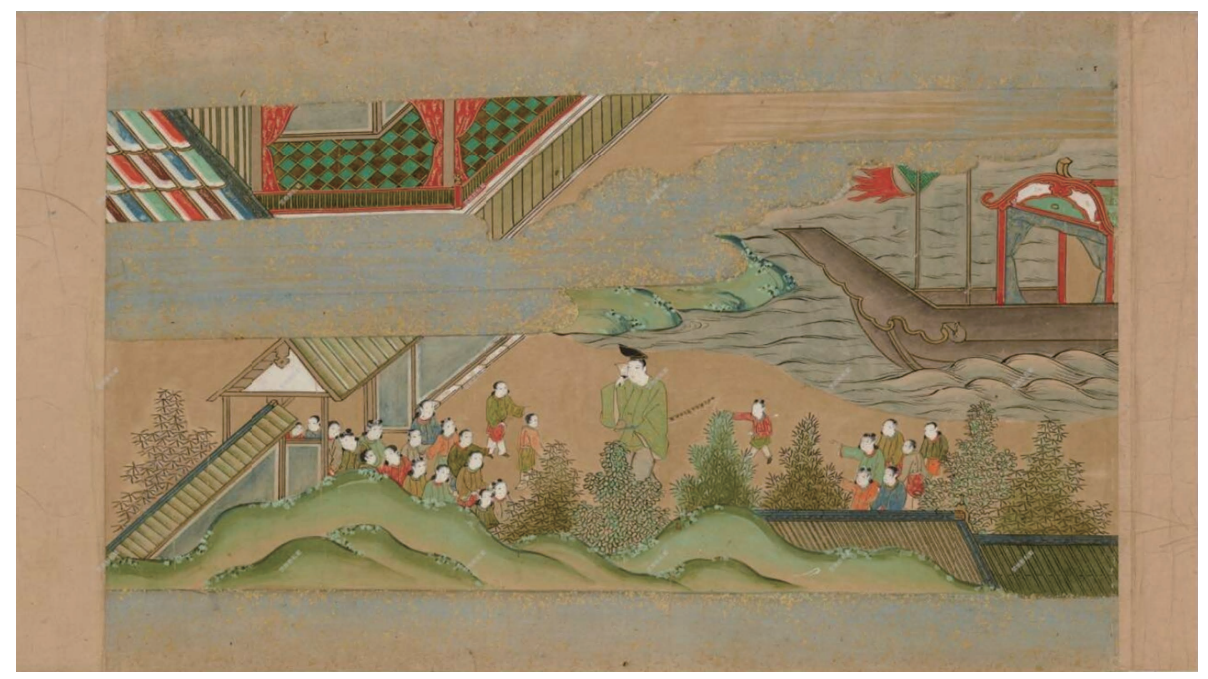

Figure 1. The artistic choice of including twenty-five of these tiny people here was likely meant to indicate the twenty-five bodhisattvas (nijugo bosatsu) believed to accompany Amida Buddha as members of the divine entourage that descended to the mortal plane to welcome faithful believers at their dying hour. "Island of the Tiny People," as depicted in the Ikenoya Collection MS.

https://doi.org/10.20730/100257436

the nature of economic trade in medieval Japan. ${ }^{3}$ While other vernacular tales, such as Tengu no dairi 天狗の内裏 (The Palace of the Tengu) and Minazuru 皆鶴 (Princess Minazuru), both of which belong to the genre of hoggan mono, are love stories that involve beautiful princess and the hunt for esoteric manuals of martial lore, Onzoshi shimawatari is unique in that it includes a journey to a distant, otherworldly island. Among literary works produced during and after the fourteenth century one may find a number of equally peculiar islands: Nyogo ga shima 女 御島, the Isle of Women; the elusive Hadaka jima 裸島, an island who inhabitants run about naked all year long; an island supposed to be populated exclusively by miniature people (see Figure 1).

How exactly all the elements found in Onzōshi shimawtari found there way into that single tale is not altogether clear. It is worth noting, however, that a number of the fantastical islands depicted in this tale appear, albeit in somewhat altered form, in poplar Chinese encyclopedias (Ch: riyong leishu; J: nichiyö ruisho) published

\footnotetext{
${ }^{3}$ See Kanazawa Hideyuki 金沢英之, Yoshitsune no bōken: eiyū to ikai wo meguru monogatari no bunka 義経の冒険一英雄と異界をめぐる物語の文化史, Tokyo: Kōdansha, 2012; Ōtani Setsuko 大谷節 子, “'Chōryō ikkan no sho’ denjutan kō: yōkyoku Kurama tengu no haikei” 「張良一巻書」伝授譚 考一謡曲「鞍馬天狗」の背景—, in Muromachi geibun ronkō 室町藝文論攻, Tokyo: Miyai Shoten, 1991; Hotate Michihisa 保立道久, Monogatari no chüsei: shinwa, setsuwa, minwa no rekishigaku 物語の 中世一神話・説話・民話の歴史学, Tōkyō Daigaku Shuppankai, 1998.
} 
during the Ming Dynasty. Many of these encyclopedias contain sections dedicated to "foreign lands," in which both real—or at least semi-real—as well as purely fictional lands are placed side by side. It has recently been established that these sections on foreign lands served as a primary source of inspiration for a Japanese vernacular tale entitled Ikoku monogatari 異国物語 ( $A$ Tale of Foreign Lands, 1658), a picture book version of which has since been introduced to the scholarly community. Onzosshi shimawatari was written during an age when the interests of authors and readers was being drawn towards an imaginary world populated not merely by the already familiar triad of China, India, and Japan, but by a whole host of far-off, purely fantastic lands. The general efflorescence at this time of what is now referred to very broadly as nature studies (bakubutsugaku 博 物学) played an important role in spurring on this imaginative movement. Consequently, Onzosshi shimawatari presents us with valuable insight into ways in which Japanese authors were manipulating both geographical and intellectual boundaries.

Illustrations accompanying medieval vernacular tales served as a visual means of imparting to readers the nature of a given boundary or liminal zone appearing within the story. One commonly cited example of this is the use of decorative wave-like patterns in a depiction of the aforementioned Kiken Castle, a motif that was utilized in many seventeenth-century illustrated scrolls and picture books as a means of signifying that the place in question was not of this world. ${ }^{4}$

While Yoshitsune was able to obtain a copy of Kanehira's esoteric manual, he was unable to lay his hands on the original. He was, furthermore, unable to take Princess Asahi away from the island with him. It would appear that artefacts and people properly belonging to other worlds can never be brought back to our mundane world. This is in perfect accord with, say, the comb case (tama tebako 玉 手箱) given to Urashima by the Dragon Princess, or the widespread taboo against gazing on otherworldly or supernatural things found in ancient Japanese literature such as the Kojiki $i$ 古事記. In Kibune no honji, already mentioned above, the male protagonist - a privileged son like Yoshitsune-first falls in love with the princess when seeing her likeness drawn on a fan. He, like Yoshitsune, is ultimately unable to take the woman back with him to the mundane world. Oñōshi shimawatari offers ample material for considerations of the nature of liminality and other worlds in medieval Japanese literature. Now that the Ikenoya Collection MS of this tale has been made publically available to a wider audience, it is hoped that more research in these areas will be forthcoming.

\footnotetext{
${ }^{4}$ Saitō Maori, "Crossing the Sea in an Illustrated Scroll: Onzōshi shimawatari in the Ikenoya Library," in The Bulletin of the National Institute of Japanese Literature, 44, March 2018, also available on-line at: http://id.nii.ac.jp/1283/00003596/. The images in question may be viewed

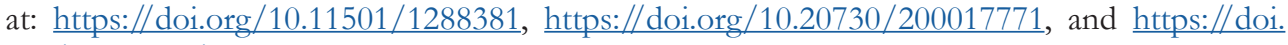
org $/ 10.20730 / 100066698$.
} 